
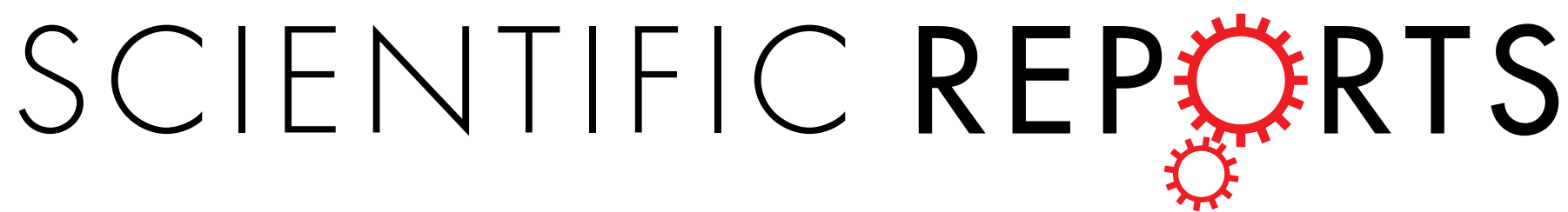

\title{
OPEN Novel mutations in CRYGD are associated with congenital cataracts in Chinese families
}

Received: 19 August 2015

Accepted: 30 November 2015

Published: 06 January 2016
Guoxing Yang ${ }^{1,2,3}$, Zhimin Chen², Wulin Zhang' ${ }^{2}$ Zhiqiang Liu² \& Jialiang Zhao ${ }^{1}$

Congenital cataract disease is a clinically and genetically heterogeneous lens disorder. The purpose of this study was to identify the genetic defects and to investigate the relationships between disease-causing genes and lens morphology in congenital cataracts. Patients were given a physical examination, and their blood samples were collected for DNA extraction. Mutation analysis was performed by direct sequencing of the following candidate genes: CRYGC, CRYGD, CRYGS, GJA8, GJA3 and CRYAA. Mutational analysis of CRYGD identified a recurrent (p.P24T) mutation in two unrelated families with congenital coralliform cataracts and three novel (p.Q101X, p.E104fsX4 and p.E135X) mutations in three families with congenital nuclear cataracts. The $\mathrm{p}$.E135X mutation is a de novo mutation. Haplotype analysis showed patients inherited the same CRYGD allele originated from father. The p.E135X mutation seen in two siblings suggests a mechanism of gonadal mosaicism in the father.

Congenital cataracts are common and cause approximately one third of infant blindness occurring in approximately 1-6 of every 10,000 live births. One quarter of congenital cataract disease cases are hereditary ${ }^{1-4}$.

Congenital cataract disease is a clinically and genetically heterogeneous lens disorder. Cataracts that are phenotypically identical can result from mutations at different genetic loci and can have different inheritance patterns. Conversely, cataracts with dissimilar phenotypes may result from mutations in a single gene or gene family. It is believed that the type of genetic mutation is related to the morphology of the cataract ${ }^{5}$. To date, about 40 genetic loci have been linked to congenital cataracts, and 26 genes have been cloned and sequenced, including crystallins, connexins, heat shock transcription factor-4, aquaporin- 0 and beaded filament structural protein- $2^{5}$.

In this study, we collected information on five families with congenital cataracts. In the follow-up genetic study, we identified four mutations in the CRYGD that is responsible for the disease.

\section{Results}

Clinical findings. Patients suffering from bilateral cataracts were diagnosed at childhood in all five families. Two families afflicted with congenital coralliform cataracts were enrolled in the Jiangxi province and the Hebei province respectively in this study. Three families afflicted with congenital nuclear cataracts had completed cataract operation in all patients. None of the participants had any other related ophthalmic syndromes.

Mutation analysis. By directly sequencing the coding region of CRYGD, we identified a recurrent (p.P24T) mutation in two unrelated families with congenital coralliform cataracts and three novel (p.Q101X, p.E104fsX4 and p.E135X) mutations in three families with congenital nuclear cataracts (Figs 1 and 2). The p.E135X mutation was identified in two affected individuals but was not found in their parents in family ZSY. These mutations were not found in healthy relatives or the 100 control populations from the same ethnic background.

Paternity testing and haplotype analysis. Paternity testing confirmed that the parents of the patients are biological parents in family ZSY. Haplotype analysis showed that two patients inherited the same CRYGD allele from their father (Fig. 3).
${ }^{1}$ Department of Opthalmology, Peking Union Medical College Hospital, Chinese Academy of Medical Sciences \& Peking Union Medical College, Beijing, China. '2Department of Opthalmology, Hebei Provincial Ophthalmic Hospital, Hebei, China. ${ }^{3} \mathrm{Hebei}$ Provincial Key laboratory of ophthalmology, Hebei, China. Correspondence and requests for materials should be addressed to J.Z. (email: zhaojialiang1234@aliyun.com) 


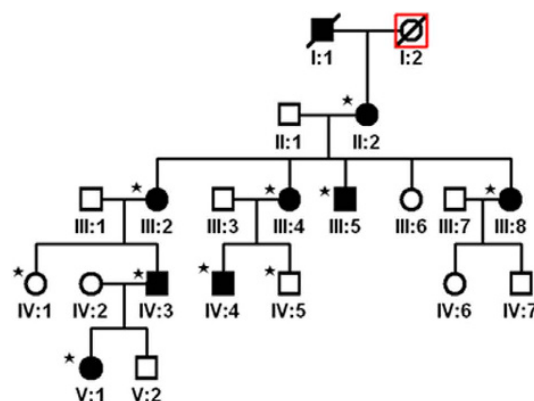

$\mathrm{M}=\mathrm{c} .70 \mathrm{C}>\mathrm{A}(\mathrm{p} . \mathrm{P} 24 \mathrm{~T})$

Family ZXM

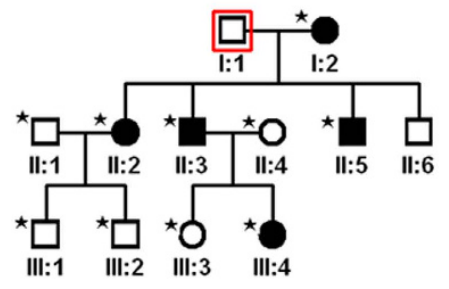

$\mathrm{M}=\mathrm{c} .70 \mathrm{C}>\mathrm{A}(\mathrm{p} \cdot \mathrm{P} 24 \mathrm{~T}) \quad \mathrm{M}=\mathrm{c} \cdot 403 \mathrm{G}>\mathrm{T}(\mathrm{p} . \mathrm{E} 135 \mathrm{X})$

Family XLB

Family ZSY

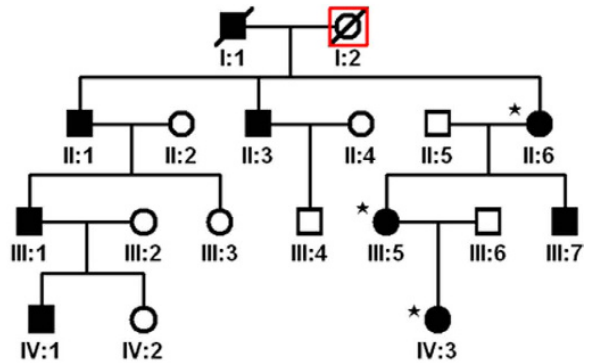

$\mathrm{M}=\mathrm{c} .309-310 \mathrm{insA}(\mathrm{p} . \mathrm{E} 104 \mathrm{fs} \mathrm{X} 4)$

Family WSS

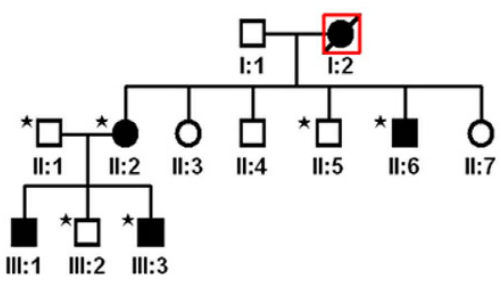

Figure 1. The pedigrees of five families with congenital cataract (Asterisk is represented the participant).

Affected

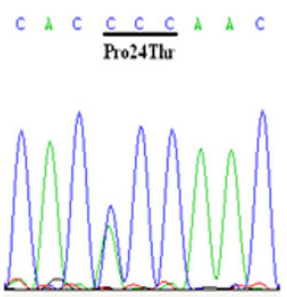

A
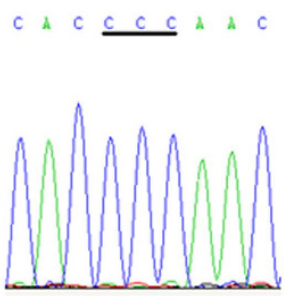

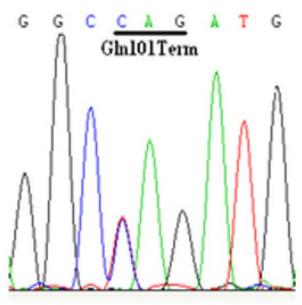

B

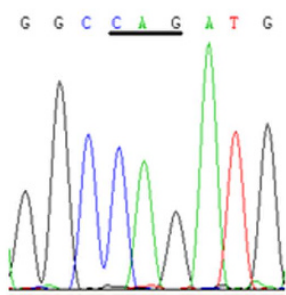

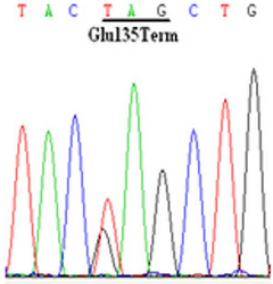

C
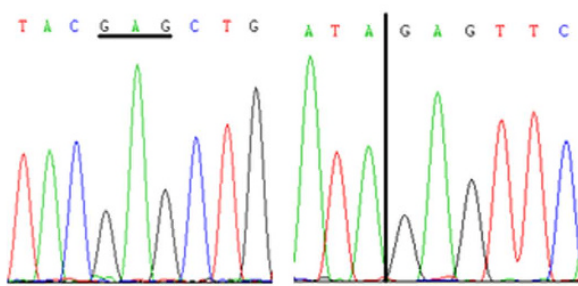

Figure 2. DNA sequences of GRYGD in affected and control individuals. Four heterozygous changes c.70C > A, c.301C > T, c.309_310insA and c.403G > T were found in the affected individuals.

\section{Discussion}

Twenty mutations in CRYGD have previously been reported (three in our study) (Table 1$)^{6-22}$. In the present study, we identified three novel mutations in CRYGD, which are predicted to cause premature stop codon and lead to the deletion of the C-terminal of protein.

CRYGD composes of two similar domains, in which each domain composes of two similar motifs. Each motif, about forty amino acid residues long, is folded in a distinctive 'Greek key' pattern. The missing residues at the C-terminus influence the folding of the Greek key motif (GKM) and then affect the biological functions of the protein.

Coralliform cataracts are a special form of congenital cataracts. Several studies have shown that mutations in the CRYGD gene can result in congenital coralliform cataracts, and the P24T mutation of CRYGD has been reported in multiple cases $^{8}$. In the two autosomal dominant congenital coralliform cataract pedigrees in this study, we identified a recurrent $\mathrm{P} 24 \mathrm{~T}$ mutation. According to the reported pedigrees, most of the congenital coralliform cataracts 
D1S72

D1S1728

chr2:208986637

CRYGD: c.403

chr2:208986385

D1S164
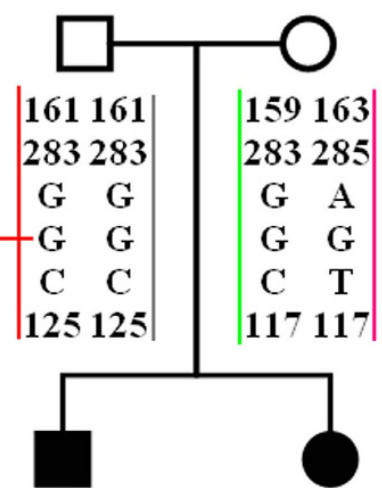

D1S72

161163

D1S1728

283285

chr2:208986637

G A

CRYGD: c.403

$-T \quad G$

chr2:208986385 $\quad$ C $\quad$ T

D1S164

125117

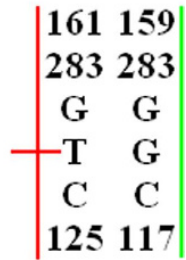

Figure 3. Paternity testing and haplotype analysis in family ZSY. Two patients inherited the same CRYGD allele from their father.

\begin{tabular}{|c|c|c|c|c|c|c|}
\hline Exon & Nucleotide & Amino acid & Inheritance & Phenotype & Origin & Ref. \\
\hline Ex2 & c. $43 \mathrm{C}>\mathrm{T}$ & p.R15C & $\mathrm{AD}$ & Punctate, Coralliform & US, China & 6 \\
\hline Ex2 & c. $43 \mathrm{C}>\mathrm{A}$ & p.R15S & $\mathrm{AD}$ & Coraliform & China & 7 \\
\hline Ex2 & c. $70 \mathrm{C}>\mathrm{A}$ & p.P24T & $\mathrm{AD}$ & $\begin{array}{c}\text { Coraliform, lamellar, } \\
\text { fasciculiform, Acueliform }\end{array}$ & $\begin{array}{l}\text { India, China, Morocco, Saudi } \\
\text { Arabia, Australia, Europe }\end{array}$ & 8 \\
\hline Ex2 & c. $70 \mathrm{C}>\mathrm{T}$ & p.P24S & $\mathrm{AD}$ & Polymorphic & Mid-Asia & 9 \\
\hline Ex2 & c. $106 \mathrm{G}>\mathrm{C}$ & p.A36P & $\mathrm{AD}$ & Nuclear & China & 10 \\
\hline Ex2 & c. $109 \mathrm{C}>\mathrm{A}$ & p.R37S & $\mathrm{S}$ & crystals & China, Czech Rep & 11 \\
\hline Ex2 & c. $110 \mathrm{G}>\mathrm{C}$ & p.R37P & $\mathrm{AD}$ & Nuclear & China & 12 \\
\hline Ex2 & c. $127 \mathrm{~T}>\mathrm{C}$ & p.W43R & $\mathrm{AD}$ & Nuclear & China & 13 \\
\hline Ex2 & c. $168 \mathrm{C}>\mathrm{G}$ & p.Y56X & $\mathrm{AD}$ & Nuclear & Brazil & 14 \\
\hline Ex2 & c. $176 \mathrm{G}>\mathrm{A}$ & p.R59H & $\mathrm{AD}$ & Aculeiform & Switzerland,Mexico & 15 \\
\hline Ex2 & c. $181 \mathrm{G}>\mathrm{C}$ & p.G61C & $\mathrm{AD}$ & Coralliform & China & 16 \\
\hline Ex2 & c. $229 \mathrm{C}>\mathrm{A}$ & p.R77S & $\mathrm{AD}$ & Anterior polar coronary & India & 17 \\
\hline Ex3 & c. $301 \mathrm{C}>\mathrm{T}$ & p.Q101X & $\mathrm{AD}$ & Nuclear & China & In this study \\
\hline Ex3 & c.309_310insA & p.E104fsX4 & $\mathrm{AD}$ & Nuclear & China & In this study \\
\hline Ex3 & c. $320 \mathrm{~A}>\mathrm{C}$ & p.E107A & $\mathrm{AD}$ & Nuclear & Mexico & 18 \\
\hline Ex3 & c. $402 \mathrm{C}>\mathrm{A}$ & p.Y134X & $\mathrm{AD}$ & Microcornea & Denmark & 19 \\
\hline Ex3 & c. $403 \mathrm{G}>\mathrm{T}$ & p.E135X & $\mathrm{AD}$ & Nuclear & China & In this study \\
\hline Ex3 & c. $418 \mathrm{C}>\mathrm{T}$ & p.R140X & $\mathrm{AD}$ & Nuclear & India, Ashkenazi Jewish & 20 \\
\hline Ex3 & c. $470 \mathrm{G}>\mathrm{A}$ & p.W157X & $\mathrm{AD}$ & Central nuclear & India & 21 \\
\hline Ex3 & c.494delG & p.G165AfsX3 & $\mathrm{AD}$ & Nuclear & China & 22 \\
\hline
\end{tabular}

Table 1. Human CRYGD mutations associated with childhood cataracts.

resulted from CRYGD mutations. This information indicates that the coralliform phenotype and the CRYGD gene are closely related. Our results support the idea that virulence genes and lens morphology are related ${ }^{23-29}$. Results of biophysical analysis have shown that the P24T mutant protein has a significantly lower solubility than wild-type human $\gamma \mathrm{D}$ crystalline $\mathrm{e}^{30,31}$.

The p.E135X mutation in family ZSY was found in two patients, but the mutation was not observed in the parents of either patient. The haplotype analysis showed that the father shares the common chromosome fragment with the children, indicating that the fathers are in a state of gonadal mosaicism ${ }^{32}$.

\section{Methods}

Patients and clinical data. Families enrolled in this study were from the Inner Mongolia Autonomous Region, Jiangxi province, Hebei province and Shandong province of China. All patients had undergone cataract surgery. Clinical examination, peripheral blood collection and DNA extraction were performed in the 
Department of Ophthalmology at the Peking Union Medical College Hospital. This study followed the tenets of the Declaration of Helsinki and was approved by the Ethics Committee of the Peking Union Medical College Hospital. The methods were carried out in accordance with the approved guidelines. Written informed consent was obtained from all participants. Clinical data for these subjects was collected through detailed ocular examinations. In addition, physical examinations were performed to exclude systemic diseases.

Mutation analysis. CRYGC, CRYGD, CRYGS, GJA8, GJA3 and CRYAA were selected as candidate genes. All coding exons for these genes were amplified by polymerase chain reaction (PCR) using a set of previously described paired primers. The PCR products were sequenced using an ABI3730 Automated Sequencer (PE Biosystems, Foster City, CA, USA).

Paternity testing and haplotype analysis. Goldeneye $\mathrm{e}^{\mathrm{TM}} 20 \mathrm{~A}$ was used to mark up the allele in different chromosomes in members of the family ZSY. Markers surrounding the gene and inside the gene were analysed to determine the haplotype of the ZSY family.

\section{References}

1. Rahi, J. S. \& Dezateux, C. British Congenital Cataract Interest Group. Measuring and interpreting the incidence of congenital ocular anomalies: lessons from a national study of congenital cataract in the UK. Invest Ophthalmol Vis Sci. 42, 1444-8 (2001).

2. Wirth, M. G., Russell-Eggitt, I. M., Craig, J. E., Elder, J. E. \& Mackey, D. A. Aetiology of congenital and paediatric cataract in an Australian population. Br J Ophthalmol. 86, 782-6 (2002).

3. Lambert, S. R. \& Drack, A. V. Infantile cataracts. Surv Ophthalmol. 40, 427-58 (1996)

4. Rahi, J. S. \& Dezateux, C. Congenital and infantile cataract in the United Kingdom: underlying or associated factors. Invest Ophthalmol Vis Sci. 41, 2108-14 (2000)

5. Hejtmancik, J. F. Cataracts and their molecular genetics. Semin Cell Dev Biol. 19, 134-49 (2008).

6. Stephan, D. A., Gillanders, E., Vanderveen, D., Freas-Lutz, D., Wistow, G., Baxevanis, A. D., Robbins, C. M., VanAuken, A., Quesenberry, M. I., Bailey-Wilson, J. et al. Progressive juvenile-onset punctate cataracts caused by mutation of the gammaD-crystallin gene. Proc Natl Acad Sci USA 96, 1008-1012 (1999).

7. Zhang, L. Y., Gong, B., Tong, J. P., Fan, D. S., Chiang, S. W., Lou, D., Lam, D. S., Yam, G. H. \& Pang, C. P. A novel gammaD-crystallin mutation causes mild changes in protein properties but leads to congenital coralliform cataract. Mol Vis. 15, 1521-1529 (2009).

8. Santhiya, S. T., Shyam Manohar, M., Rawlley, D., Vijayalakshmi, P., Namperumalsamy, P., Gopinath, P. M., Loster, J. \& Graw, J. Novel mutations in the gamma-crystallin genes cause autosomal dominant congenital cataracts. J Med Genet. 39, 352-8 (2002).

9. Plotnikova, O. V., Kondrashov, F. A., Vlasov, P. K., Grigorenko, A. P., Ginter, E. K. \& Rogaev, E. I. Conversion and compensatory evolution of the gamma-crystallin genes and identification of a cataractogenic mutation that reverses the sequence of the human CRYGD gene to an ancestral state. Am J Hum Genet. 81, 32-43 (2007).

10. Sun, W., Xiao, X., Li, S., Guo, X. \& Zhang, Q. Mutation analysis of 12 genes in Chinese families with congenital cataracts. Mol Vis. 17, 2197-2206 (2011).

11. Kmoch, S., Brynda, J., Asfaw, B., Bezouska, K., Novák, P., Rezácová, P., Ondrová, L., Filipec, M., Sedlácek, J. \& Elleder, M. Link between a novel human $\gamma \mathrm{D}$-crystallin allele and a unique cataract phenotype explained by protein crystallography. Hum Mol Genet. 9, 1779-86 (2000).

12. Wang, L., Chen, X., Lu, Y., Wu, J., Yang, B. \& Sun, X. A novel mutation in gammaD-crystallin associated with autosomal dominant congenital cataract in a Chinese family. Mol Vis. 17, 804-809 (2011).

13. Wang, B., Yu, C., Xi, Y. B., Cai, H. C., Wang, J., Zhou, S., Zhou, S., Wu, Y., Yan, Y. B., Ma, X. et al. A novel CRYGD mutation (p. Trp43Arg) causing autosomal dominant congenital cataract in a Chinese family. Hum Mutat. 32, E1939-1947 92011).

14. Santana, A., Waiswol, M., Arcieri, E. S., Cabral de Vasconcellos, J. P. \& Barbosa de Melo, M. Mutation analysis of CRYAA, CRYGC, and CRYGD associated with autosomal dominant congenital cataract in Brazilian families. Mol Vis. 15, 793-800 (2009).

15. Héon, E., Priston, M., Schorderet, D. F., Billingsley, G. D., Girard, P. O. \& Lubsen, N., Munier FL.The gamma-crystallins and human cataracts: a puzzle made clearer. Am J Hum Genet. 65, 1261-7 (1999).

16. Li, F., Wang, S., Gao, C., Liu, S., Zhao, B., Zhang, M., Huang, S., Zhu, S. \& Ma, X. Mutation G61C in the CRYGD gene causing autosomal dominant congenital coralliform cataracts. Mol Vis. 14, 378-86 (2008).

17. Roshan, M., Vijaya, P. H., Lavanya, G. R., Shama, P. K., Santhiya, S. T., Graw, J., Gopinath, P. M. \& Satyamoorthy, K. A novel human CRYGD mutation in a juvenile autosomal dominant cataract. Mol Vis. 16, 887-896 (2010).

18. Messina-Baas, O. M., Gonzalez-Huerta, L. M. \& Cuevas-Covarrubias, S. A. Two affected siblings with nuclear cataract associated with a novel missense mutation in the CRYGD gene. Mol Vis. 12, 995-1000 (2006).

19. Hansen, L., Mikkelsen, A., Nurnberg, P., Nurnberg, G., Anjum, I., Eiberg, H. \& Rosenberg, T. Comprehensive mutational screening in a cohort of Danish families with hereditary congenital cataract. Invest Ophthalmol Vis Sci. 50, 3291-3303 (2009)

20. Devi, R. R., Yao, W., Vijayalakshmi, P., Sergeev, Y. V., Sundaresan, P. \& Hejtmancik, J. F. Crystallin gene mutations in Indian families with inherited pediatric cataract. Mol Vis. 14, 1157-1170 (2008)

21. Santhiya, S. T., Shyam Manohar, M., Rawlley, D., Vijayalakshmi, P., Namperumalsamy, P., Gopinath, P. M., Loster, J. \& Graw, J. Novel mutations in the gamma-crystallin genes cause autosomal dominant congenital cataracts. J Med Genet. 39, 352-358 (2002).

22. Zhang, L. Y., Yam, G. H., Fan, D. S., Tam, P. O., Lam, D. S. \& Pang, C. P. A novel deletion variant of gammaD-crystallin responsible for congenital nuclear cataract. Mol Vis. 13, 2096-2104 (2007).

23. Mackay, D. S., Andley, U. P. \& Shiels, A. A missense mutation in the gammaD crystallin gene (CRYGD) associated with autosomal dominant "coral-like" cataract linked to chromosome 2q. Mol Vis. 10, 155-62 (2004).

24. Shentu, X., Yao, K., Xu, W., Zheng, S., Hu, S. \& Gong, X. Special fasciculiform cataract caused by a mutation in the gammaDcrystallin gene. Mol Vis. 10, 233-9 (2004).

25. Xu, W. Z., Zheng, S., Xu, S. J., Huang, W., Yao, K. \& Zhang, S. Z. Autosomal dominant coralliform cataract related to a missense mutation of the gammaD-crystallin gene. Chin Med J (Engl). 117, 727-32 (2004).

26. Nandrot, E., Slingsby, C., Basak, A., Cherif-Chefchaouni, M., Benazzouz, B., Hajaji, Y., Boutayeb, S., Gribouval, O., Arbogast, L., Berraho, A., Abitbol, M. \& Hilal, L. Gamma-D crystallin gene (CRYGD) mutation causes autosomal dominant congenital cerulean cataracts. J Med Genet. 40, 262-7 (2003).

27. Khan, A. O., Aldahmesh, M. A. \& Ghadhfan, F. E. Founder heterozygous P23T CRYGD mutation associated with cerulean (and coralliform) cataract in 2 Saudi families. Mol Vis. 15, 1407-11 (2009).

28. Santhiya, S. T., Shyam Manohar, M., Rawlley, D., Vijayalakshmi, P., Namperumalsamy, P., Gopinath, P. M., Löster, J. \& Graw, J. Novel mutations in the gamma-crystallin genes cause autosomal dominant congenital cataracts. J Med Genet. 39, 352-8 (2002).

29. Yang, G. X., Xiong, C. L., Li, S. L., Wang, Y. Y. \& Zhao, J. L. A recurrent mutation in CRYGD is associated with autosomal dominant congenital coralliform cataract in two unrelated Chinese families. Mol Vis. 17, 1085-1089 (2011).

30. Evans, P., Wyatt, K., Wistow, G. J., Bateman, O. A., Wallace, B. A. \& Slingsby, C. The P23T cataract mutation causes loss of solubility of folded gammaD-crystallin. J Mol Biol. 343, 435-44 (2004). 
31. Jung, J., Byeon, I. J., Wang, Y., King, J. \& Gronenborn, A. M. The structure of the cataract-causing P23T mutant of human gammaDcrystallin exhibits distinctive local conformational and dynamic changes. Biochemistry. 48, 2597-609 (2009).

32. Liu, G., Chen, X., Sun, X., Liu, H., Zhao, K., Chang, Q., Pan, X., Wang, X., Yuan, S., Liu, Q. \& Zhao, C. Maternal germline mosaicism of kinesin family member 21A (KIF21A) mutation causes complex phenotypes in a Chinese family with congenital fibrosis of the extraocular muscles. Mol Vis. 20, 15-23 (2014).

\section{Author Contributions}

Study design G.X.Y. and J.L.Z. Collected the samples and performed the experiments G.X.Y., W.L.Z., Z.M.C. and Z.Q.L. Data interpretation and analysis: G.X.Y. Wrote the manuscript: G.X.Y. All authors have read and approved the final manuscript.

\section{Additional Information}

Competing financial interests: The authors declare no competing financial interests.

How to cite this article: Yang, G. et al. Novel mutations in CRYGD are associated with congenital cataracts in Chinese families. Sci. Rep. 6, 18912; doi: 10.1038/srep18912 (2016).

(c) (i) This work is licensed under a Creative Commons Attribution 4.0 International License. The images or other third party material in this article are included in the article's Creative Commons license, unless indicated otherwise in the credit line; if the material is not included under the Creative Commons license, users will need to obtain permission from the license holder to reproduce the material. To view a copy of this license, visit http://creativecommons.org/licenses/by/4.0/ 